gives $\dot{\epsilon}$ parallel to the surface for each interval, and hence the difference $\Delta \dot{\epsilon}$ between successive intervals. Thus no transformation of coordinates appears to be necessary.

In short, I believe that my equations (which are the same for small slopes as those of Budd, but with the variables more precisely defined) can be applied directly to the field measurements. Indeed they have already been applied-by Robin and Budd.

H. H. Wills Physics Laboratory, J. F. NYE

University of Bristol, Tyndall Avenue, Bristol BS8 I TL, England I3. November 1969

SIR, Glaciation of the north-western part of the Canadian Arctic Archipelago

In a recent paper (Paterson, I969), I stated that the islands in the north-western part of the Archipelago are marked "unglaciated" on the Glacial map of Canada. I am grateful to Dr W. Blake, Jr for pointing out that, whereas my statement is true for the $195^{8}$ edition of the map, it is not true for the latest (1968) edition. On the 1968 map, only Banks Island and a small part of southern Melville Island are marked "unglaciated". It is now believed that the remainder of the islands were covered by a large ice sheet during the last glaciation (Blake, 1970).

Polar Continental Shelf Project,

W. S. B. Paterson

Department of Energy, Mines and Resources, Ottawa, Ontario, Canada

I7 December 1969

\title{
REFERENCES
}

Blake, W.,jr. 1970. Studies of glacial history in Arctic Canada. I. Pumice, radiocarbon dates, and differential postglacial uplift in the eastern Queen Elizabeth Islands. Canadian Fournal of Earth Sciences, Vol. 7, No. 2, Pt. 2, p. $634-64$.

Paterson, W. S. B. 1969. The Meighen Ice Cap, Arctic Canada: accumulation, ablation and flow. Fournal of Glaciology, Vol. 8, No. 54, p. $34^{1-52}$.

SIR,

\section{Distorted ice stalactites as indicators of glacier movement}

During August 1969 we were working in the Mt Castleguard locality, Alberta, Canada. The mountain stands at the eastern end of the Columbia Icefield and hosts a number of small temperate glaciers of its own. One of these terminates at an altitude of $8200 \mathrm{ft}(2500 \mathrm{~m})$ upon a broad gentle limestone bench. There was an ice cave at the snout which could be followed up the line of ice flow for approximately roo m. A cross-section is given in Figure I. Inside the cave, rock and glacier-ice surfaces were decorated with abundant sublimation ice deposits.

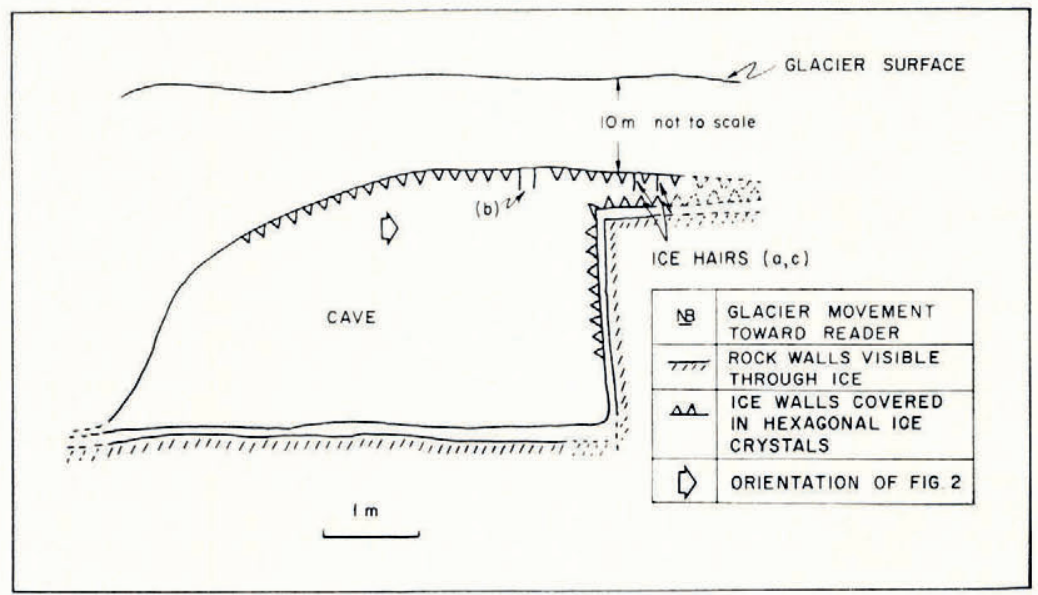

Fig. I. 